Article

\title{
(Dis)Trust, Control, and Project Success: From a Chinese Project Owner's Perspective
}

\author{
Weiping Jiang ${ }^{1, *}$, Xianbo Zhao ${ }^{2}$ (D) and Jian Zuo ${ }^{3}$ \\ 1 School of Civil Engineering, Shenzhen University, Shenzhen 518060, China \\ 2 School of Engineering and Technology, Central Queensland University, Sydney 2000, Australia; \\ b.zhao@cqu.edu.au \\ 3 School of Architecture and Built Environment; Entrepreneurship, Commercialisation and Innovation \\ Centre (ECIC), The University of Adelaide, Adelaide 5005, Australia; jian.zuo@adelaide.edu.au \\ * Correspondence: swingopen@szu.edu.cn; Tel.: +86-0755-3601-3879
}

Received: 10 September 2017; Accepted: 23 October 2017; Published: 31 October 2017

\begin{abstract}
This research aims to investigate the relationship between interorganizational trust and control and their effects on the project success from the perspective of project owners. Based on relevant literature and the actual situation in the Chinese construction industry, trust was classified as calculative trust and relational trust, and control was classified as outcome control, behavior control, and social control. Results show that project owners' distrust of contractors is independent of project owners' trust of contractors. Calculative trust has a positive influence on all kinds of control. Relational trust has negative impacts on outcome control and behavior control and positive impacts on social control. Of the three kinds of control, outcome and behavior control have negative impacts on social control. All constructs have positive impacts on project success. Project managers should be aware that distrust has a positive influence on project success through the mediation effects of control. Similarly, social control is the most influential type of control, influencing the controller to internalize norms to complete project tasks.
\end{abstract}

Keywords: trust; distrust; control; project success; structural equation modeling (SEM)

\section{Introduction}

Trust has drawn wide attention in the field of management research, including construction-project management [1-3]. Trust is defined by Rousseau et al. [4] as a psychological state comprising the intention to accept vulnerability, based on positive expectations of intentions or behaviors of another. Previous studies reported that higher levels of trust contribute to exceptional project performance and promote cooperation among stakeholders [5]. For example, Black et al. [6] suggested that "mutual trust" is one of the most critical factors in maintaining partnerships.

Although trust has a significant influence on project cooperation, trust cannot resolve all problems during the cooperation process [7]. Indeed, interorganizational control is another important factor in achieving project success [8]. Control is traditionally regarded as the backbone of organizational performance, focused on mechanisms such as organizational structure, formalization, and hierarchy. Control is "a regulatory process by which the elements of a system are made more predictable through the establishment of standards in the pursuit of some desired objective or state" [9]. No consensus exists on the relationship between trust and control in interorganizational relationships.

Moreover, it is well recognized that complete trust does not exist [10]. Trust and distrust coexist, as one may trust another in some ways and distrust another in other ways, affecting the ability to cooperate [11]. Often, trust is operationalized on a continuum bounded by the diametric poles of trust and distrust [12]. However, a growing number of studies suggested that trust and distrust are separate but related constructs $[10,13,14]$, so that low trust does not necessarily mean high distrust. Sitkin and 
Roth [15] defined distrust as "a belief that a person's values or motives will lead them to approach all situations in an unacceptable manner." Most trust theorists agree that trust and distrust are separate and opposite constructs [16].

In construction projects, the relationship between project owners and contractors is generally temporary. In this temporary cooperation, trust and distrust from the owners coexist and influence owners' control measures. Generally, project owners themselves have no ability to control project progress and must rely on contractors. As a result, owners take control measures and contractors can complete project targets. This study examines owners' control measures of contractors, discerning the relationship among trust, distrust, and control by project owners with contractors, and their influence on project success.

This study has implications for theory and practice. First, by combining trust, distrust, and control in the same frame, one can observe their collective effect on project success. The vast majority of extant studies examined the relationship between trust and distrust or between trust and control separately $[17,18]$. This study develops a framework integrating trust, distrust, and control into a single framework and explores the relationships among them. Its findings enrich the body of knowledge on project management. Second, this study provides useful references for owners' project managers to collaborate with contractors toward achieving project success.

\section{Background and Conceptual Framework}

\subsection{Interorganization Control}

Control is a term widely used in the disciplines of manufacturing and management. Organizations have paid attention to the capability of planning, resource allocation, and control functions to ensure project objectives are achieved [19-22]. This approach to project management assumes all the organizations work as a whole and has neglected the interorganizational relationship of participants in overall project success.

Three kinds of control strategy in management are outcome control, behavior control, and social control [23-25]. Outcome control and behavior control are forms of formal control [26]. Formal control emphasizes the establishment and use of formal rules, procedures, processes, and policies to monitor and reach desirable objectives [24]. Social control, also called informal control, relies on establishing organizational norms and values [27].

While measuring outcomes relies on accurate assessment of participant performance, measuring behavior aims to ensure the process is appropriate [24]. Social control is also called clan control [28]. Clan control is suitable in an environment with no specifying task-related behaviors and outputs. Clan control focuses on developing shared values, beliefs, and goals to reinforce appropriate behavior. Participants are motivated to achieve goals if project organizational goals are internalized. In short, outcome control is suitable in organizations with high outcome measurability: the ability to measure output in a precise and objective manner. Behavior control is suitable in those project organizations with high task programmability, which references the degree to which managers understand the processes in which appropriate behaviors take place. Social control is suitable in project organizations with tasks that can hardly be monitored by output standard or processes.

Therefore, in terms of functions, formal control and informal control supplement each other. Generally, the owner and contractor initially cooperate at the early stages of a project. The contract describes project targets and project rules include work processes [29-31]. In other words, outcome control and behavior control are prominent in the early stages of a project. However, social control develops with relationship development between the two partners, according to the strength of formal control. Therefore, the following are hypothesized

Hypothesis 1a (H1a): The owner's outcome control negatively influences the contractor's social control.

Hypothesis $\mathbf{1 b}(\mathbf{H 1 b})$ : The owner's behavior control negatively influences the contractor's social control. 


\subsection{Relationship between Trust/Distrust and Control}

\subsubsection{Relationship between Trust and Control}

First impressions are very important for cooperation between partners. According to path-dependency theory, first impressions lay the foundation for cooperation. In construction-project organizations, the owner and contractor generally cooperate initially, owing to the temporary nature of construction projects. Although the owner and contractor may have cooperated previously, the members of the two organizations need to rebuild trust.

Trust has significant impacts on project partners' relationship. First, calculative trust has a certain influence on project control. Calculative trust is the rational component of trust [32]. Calculative trust is also called rational trust or deterrence-based trust [33]. In construction projects, calculative trust does not mean clients relax their vigilance against contractors. In project-organization relationships, calculative trust results from thorough consideration of the other partner's competency and one's own profit. Greater calculative trust accompanies more rationality, expressed in greater control, such as stricter contracts and procedures, or value and cultural influence. Thus, the following are hypothesized:

Hypothesis 2a (H2a): Calculative trust positively influences outcome control.

Hypothesis 2b (H2b): Calculative trust positively influences behavior control.

Hypothesis 2c (H2c): Calculative trust positively influences social control.

Unlike calculative trust, relational trust is the emotional aspect of trust [32]. Relational trust has been labeled affect-based or identification-based [34,35]. Rousseau and colleagues [4] referred to trust motivated by these social-psychological bonds as relational trust. Relational trust is a kind of real trust, with no calculation [36].

Emphasizing mutual respect and shared interests, relational trust provides an effective tool beyond those organizational controls [37,38]. Das and Teng [38] indicated that trust and control are "two completely different kinds of approaches. When it is possible to fully trust a partner, there is no need to control its behavior. Control comes into play only when adequate trust is not present." Thus, the following are hypothesized:

Hypothesis 2d (H2d): Relational trust negatively influences outcome control.

Hypothesis 2e (H2e): Relational trust negatively influences behavior control.

Hypothesis 2f (H2f): Relational trust negatively influences social control.

\subsubsection{Relationship between Distrust and Control}

Distrust is a negative expectation about another's intention or conduct $[10,14,39]$. It is well recognized that distrust inevitably leads to more control measures [40-42]. When distrust exists, it is more likely someone will be maliciously treated [41]. Maliciously treatment may lead to preventive actions against the effects of the other's behavior, especially guiding or restricting the other's conduct through contract agreement, behavior control, or cultural influence.

In construction projects, the relationship between distrust and control is prominent. When distrust level of the other partner rises, it is more likely the distrusting person will seek contract documents. Zaghloul and Hartman [43] investigated the construction industry in Canada; they pointed out that current contractual relationships mainly rest on confrontational situations that reflect the level of distrust in contract documents. Owing to distrust about the other partner, contracts are always written with numerous clauses. Thus, the following is hypothesized: 
Hypothesis 3a (H3a): Distrust positively influences outcome control.

Beyond contract control measures, the owner may also employ behavior management to control the behavior of the contractor owing to the existence of distrust. Due to the information asymmetry between the owner and contractor, the owner may strengthen behavior control to ensure the project is in the controlled state. In the Chinese construction industry, owners always employ supervision engineers to monitor the construction process on site [44]. Thus, the following is hypothesized:

Hypothesis 3b (H3b): Distrust positively influences behavior control.

In addition, the owner may use social control measures when experiencing distrust. Social control is an alternative to formal control [23]. Social control uses culture and value to influence the other partner. When the other internalizes the value, the aim of social control is fulfilled [24]. Thus, the following is hypothesized:

Hypothesis 3c (H3c): Distrust positively influences social control.

\subsection{Project Success}

Project success has been extensively examined in the project-management literature [45-47]. Project success means different things to different project stakeholders [48,49]. In this paper, project success is examined from the perspective of the owners. Project success is the degree to which project goals and expectations are met $[50,51]$.

It is well recognized that trust has important influences on project success [3,52-56]. Thus, the following are hypothesized:

Hypothesis 4a (H4a): Calculative trust positively influences project success.

Hypothesis $4 \mathbf{b}$ (H4b): Relationship trust positively influences project success.

Distrust also has a notable influence on cooperation performance resulting from the two partners' work. Very few studies directly concern the relationship between distrust and project performance in the project-management literature. However, abundant relevant research in E-commerce is referenced in this research.

Carol and Choon [57] conducted an empirical study on consumers' trust and distrust of websites. Their study suggested that trust and distrust are two distinct constructs, whereas distrust prevents a consumer from buying on a website and requires greater attention. Benamati and Serva [58] recommended that online banks build trust but not ignore the powerful synergy of consumer distrust. McKnight and Choudhury [59] argued that trust and distrust are distinct concepts, suggesting distrust is an important predictor for business-to-consumer actions such as willingness to share information and willingness to purchase. Thus, the following is hypothesized:

Hypothesis 5 (H5): Distrust negatively influences project success.

Control is an important function of management [60] and is critical to project performance [61]. Referring to interorganizational control, different types of control have specific implications. According to Das and Teng [24], behavior control focuses on the process that can turn appropriate behavior into desirable outcomes. Behavior control is suitable when opportunistic behavior and relational conflict are difficult to measure precisely and objectively. Behavior-control mechanisms are used to regulate the other partner's conduct to prevent major surprises, thereby reducing relational risk. In contrast, outcome control is not associated with relational-risk management [24]. 
Outcome control is more relevant to performance risk, which can be measured in a precise way [24]. Performance risk relates to organization performance or the outcome of the other partner's activities. Therefore, outcome control is an effective way to reduce performance risk.

Social control aims to align organizational goals by establishing a common culture and values [62]. The value of social control is more significant in cases of low-output measurability and process programmatically. Social control is capable of addressing relational risk and performance risk simultaneously [24].

In construction projects, outcome control mainly manifests in contract clauses to define project outcomes. The owner generally describes the desirable outcome of the project in the contract with the contractor, such as cost and schedule. Outcome control cannot effectively address opportunistic behavior, which occurs in construction projects because of asymmetric information between the owner and the contractor. Thus, the owner may set up a series of process regulations to monitor the contractor's behavior: hence, behavior control. Beyond outcome control and behavior control, social control exists to influence the partner's culture and value in construction projects. Though the utility of social control is not as impactful as outcome control and social control, it can be used to internalize the cultural influence for the contractor and makes it beneficial for the contractor to execute orders more aligned with the aim of the owner. Therefore, the following are hypothesized:

Hypothesis 6a (H6a): Outcome control positively influences project success.

Hypothesis 6b (H6b): Behavior control positively influences project success.

Hypothesis 6c (H6c): Social control positively influences project success.

All these hypotheses form the conceptual framework of this study (see Figure 1). This conceptual framework was tested with empirical data.

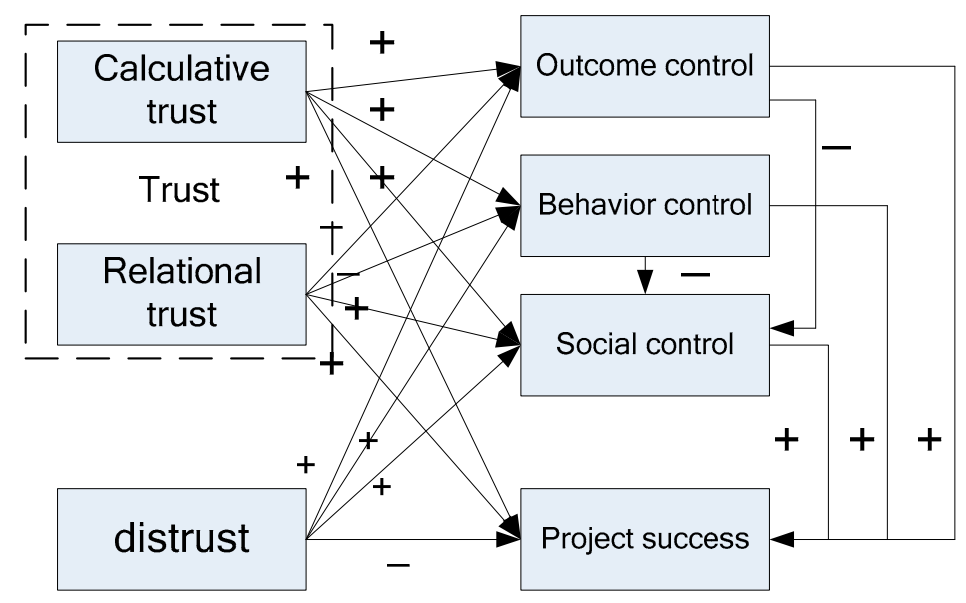

Figure 1. Conceptual framework of this research.

\section{Research Methodology}

\subsection{SEM and Linear Regression}

Structural equation modeling (SEM) was adopted for this study to test the proposed conceptual model and the proposed links among the constructs. SEM was employed to test all hypotheses. SEM has advantages when conducting empirical research in construction-project management: (1) SEM can explain an entire set of relationships of the constructs in the conceptual model, (2) SEM can estimate 
multiple and interrelated dependence in the relationships of the constructs, and (3) SEM considers measurement errors in estimation [63].

The SEM method consists of six steps [5,52]: (1) questionnaire design, (2) pilot testing, (3) large-sample data collection, (4) running of the model, (5) model validation and revision, and (6) analysis of the final results. This method has been widely used in construction management studies $[64,65]$. The first three steps are described in this section, and the other steps are in the following sections.

\subsection{Questionnaire Design}

The research model covers seven factors measured by multiple items. All items were identified from the literature to improve content validity. Questionnaire items were translated into Chinese. Six experts and scholars were asked to modify the Chinese version of the questionnaire. Subsequently, three lecturers in language studies were asked to translate the questionnaire back into English to ensure the accuracy of the translation. All items were measured on a seven-point Likert-type scale ranging from strongly disagree (1) to strongly agree (7).

Items of calculative trust were adapted from Handfield and Bechtel [66], Zaheer et al. [67] and Yang [68]. All seven terms of relational trust were adapted from McAllister [34]. Items of distrust were adapted from Chen [69]. All four items consider negative attitude about the other's attention or behavior.

Items of outcome control were adapted from three sources. One item was adapted from Jap and Ganesan [70], two from Zhang [71], and two from Cheung [72]. Items of behavior control were adapted from Cheung et al. [73]. All items of social control were adapted from Zhang [71].

Items of project success were adapted from Jeffrey et al. [74] and Jugdev and Muller [75]. Nine items were adapted from Jeffrey et al. [74] and have high reliability. One item was adapted from Jugdev and Muller [75].

\subsection{Pilot Test}

The preliminary questionnaire was pilot tested by four experts. Two were university professors in construction-project management with more than 15 years of research experience. The other two were construction-project managers with more than 20 years of experience in construction-project management for owners. The experts were asked to critically review the design and structure of the questionnaire. Comments about the questionnaire were positive, and no changes were made.

\subsection{Data Collection}

The survey was carried out between July 2012 and December 2013. The targeted respondents were drawn from owners' project managers. Of the 600 questionnaires sent out, 366 responses were received, with a response rate of $61 \%$. This is comparable to previous SEM studies, such as that by Shan et al. [76], with 188 cases, and by Anvuur and Kumaraswamy [77], with 153 cases (18\% response rate). The responses exceeded the minimum of 100 cases necessary for SEM suggested by Gorsuch [78] and Bagozzi and Yi [79]. Of respondents, $17 \%$ have been the owner's project manager for 1-5 years, $27 \%$ for $6-10$ years, $20.8 \%$ for $11-15$ years, $15.0 \%$ for $16-20$ years, and $21.2 \%$ for more than 20 years. Initial screening showed that 28 returned questionnaires were incomplete. As a result, 338 responses were further analyzed.

\section{Results}

\subsection{The Results of the Measurement Model}

Exploratory factor analysis was conducted. Results showed a seven-factor structure of all 37 items (see Table 1). 
Table 1. Factor analysis results.

\begin{tabular}{ccc}
\hline Constructs & Number of Items & Accumulation Percentage \\
\hline Calculative trust & 6 & 65.328 \\
Relational trust & 7 & 61.940 \\
Distrust & 4 & 66.198 \\
Outcome control & 5 & 58.962 \\
Behavior control & 4 & 65.081 \\
Social control & 3 & 69.098 \\
Project success & 8 & 66.310 \\
\hline
\end{tabular}

Furthermore, the reliability and validity of the constructs were tested. As shown in Table 2, the loadings of all items of the seven constructs were significant. Cronbach's alpha $(\alpha)$, another measure of the reliability [80], were above 0.7 (see Table 2). Therefore, the measurement model of this research was acceptable in reliability $[63,81,82]$. Moreover, for internal consistency reliability, the composite reliability (CR) score should be above 0.70 [83], as shown in Table 2.

Table 2. The items' loadings $(\lambda)$ and the constructs' Cronbach's $\alpha$ coefficients and composite reliability (CR).

\begin{tabular}{|c|c|c|c|c|}
\hline Constructs & Items & $\lambda$ & Cronbach's $\alpha$ & CR \\
\hline \multirow{6}{*}{ Calculative trust } & CAL2 & 0.810 & \multirow{6}{*}{0.883} & \multirow{6}{*}{0.894} \\
\hline & CAL3 & 0.778 & & \\
\hline & CAL4 & 0.731 & & \\
\hline & CAL5 & 0.790 & & \\
\hline & CAL6 & 0.734 & & \\
\hline & CAL7 & 0.741 & & \\
\hline \multirow{7}{*}{ Relative trust } & REL1 & 0.723 & \multirow{7}{*}{0.904} & \multirow{7}{*}{0.898} \\
\hline & REL2 & 0.789 & & \\
\hline & REL3 & 0.79 & & \\
\hline & REL4 & 0.748 & & \\
\hline & REL5 & 0.705 & & \\
\hline & REL7 & 0.758 & & \\
\hline & REL8 & 0.703 & & \\
\hline \multirow{4}{*}{ Distrust } & DT1 & 0.729 & \multirow{4}{*}{0.830} & \multirow{4}{*}{0.830} \\
\hline & DT2 & 0.764 & & \\
\hline & DT3 & 0.735 & & \\
\hline & DT4 & 0.737 & & \\
\hline \multirow{5}{*}{ Outcome control } & OC1 & 0.690 & \multirow{5}{*}{0.816} & \multirow{5}{*}{0.895} \\
\hline & OC2 & 0.732 & & \\
\hline & OC3 & 0.702 & & \\
\hline & OC4 & 0.666 & & \\
\hline & OC5 & 0.698 & & \\
\hline \multirow{4}{*}{ Behavior control } & PC1 & 0.694 & \multirow{4}{*}{0.843} & \multirow{4}{*}{0.879} \\
\hline & PC2 & 0.734 & & \\
\hline & PC3 & 0.724 & & \\
\hline & PC4 & 0.770 & & \\
\hline \multirow{3}{*}{ Social control } & SC1 & 0.800 & \multirow{3}{*}{0.843} & \multirow{3}{*}{0.856} \\
\hline & SC2 & 0.710 & & \\
\hline & SC3 & 0.689 & & \\
\hline \multirow{8}{*}{ Project success } & SUC1 & 0.792 & \multirow{8}{*}{0.938} & \multirow{8}{*}{0.939} \\
\hline & SUC2 & 0.814 & & \\
\hline & SUC3 & 0.607 & & \\
\hline & SUC4 & 0.793 & & \\
\hline & SUC5 & 0.788 & & \\
\hline & SUC7 & 0.843 & & \\
\hline & SUC8 & 0.789 & & \\
\hline & SUC9 & 0.835 & & \\
\hline
\end{tabular}




\subsection{Results of the Structural Model}

SEM provides a useful tool to examine the causal relationship between construct variables. Several indices evaluate the goodness of fit of the model. First, basic indices such as $\chi^{2} / \mathrm{df}$ were less than 3 [84]; root mean square error of approximation was less than 0.1 [85]. Other goodness indices include a goodness-of-fit index greater than 0.85 , an adjusted goodness-of-fit index greater than 0.85 , an incremental-fit index (IFI) greater than 0.85, and a comparative-fit index (CFI) greater than 0.85 [86]. After setting all the rules, the covariance-based SEM calculation was carried out using Lisrel 8.50, which is a professional software program designed for SEM analysis.

The running result demonstrates that $\chi^{2} / \mathrm{df}=1.76$, which is less than $3 ; 0.048<0.1 ; 0.960 ; 0.985$; $\mathrm{IFI}=0.986 ; \mathrm{CFI}=0.999$. From the goodness-of-fit indices, the model is acceptable. In the measurement model, all load values of observed variables are above zero and are significant. In the structural model, all standardized values of the paths are under 1 . Therefore, no change is required to this model.

The entire SEM is shown in Figure 2. All standardized path values are shown in Table 3. Results show that trust, distrust, and control have direct impact on project success. Similarly, trust and distrust also have indirect impact on project success through the mediation of control. In addition, outcome control and behavior control have direct influence on social control. In conclusion, all hypotheses are supported, except H3f.

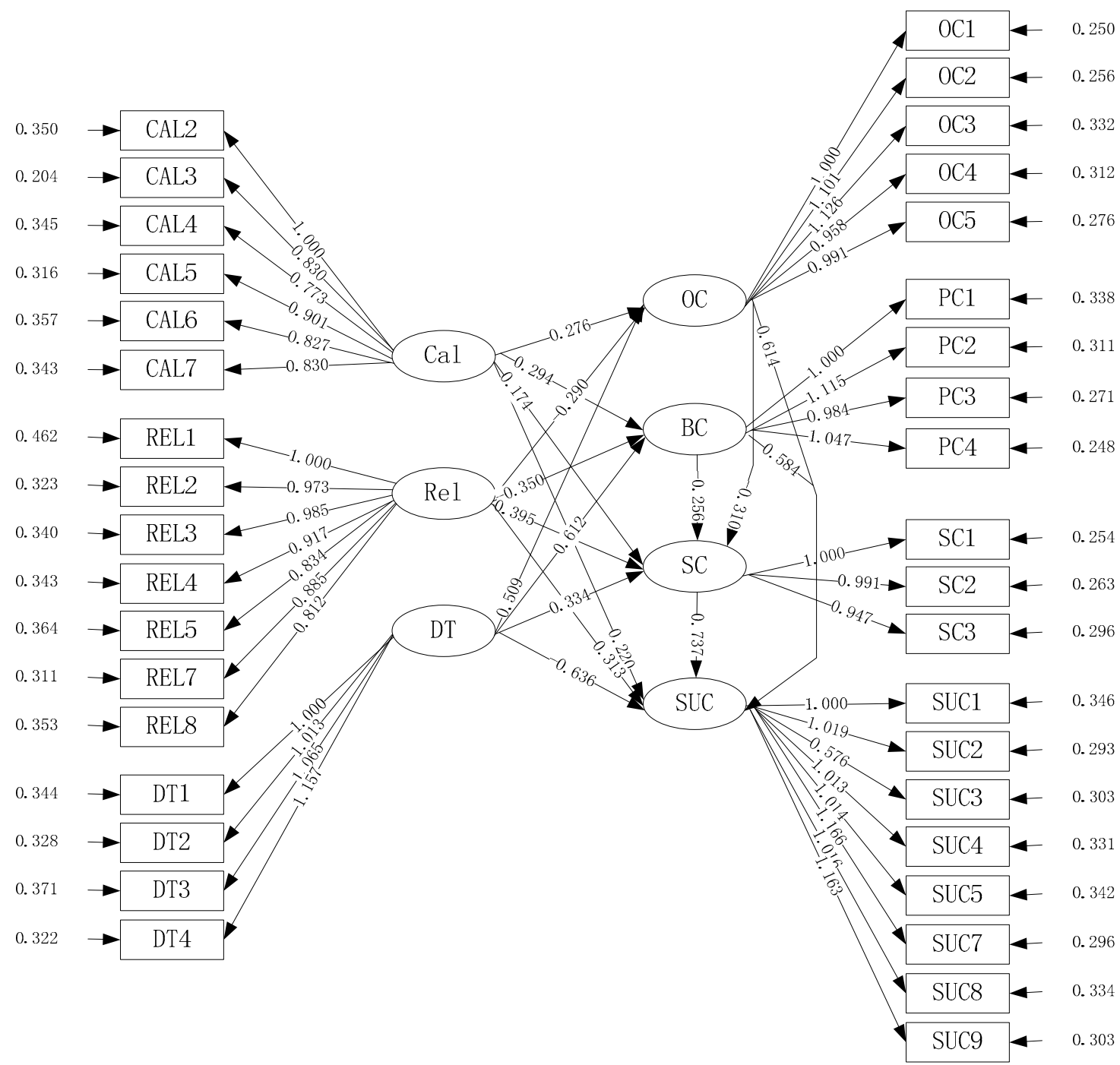

Figure 2. The calculation results of the structural equation model. 
In addition, calculation of the direct and indirect influence of various factors (calculative trust, relational trust, and distrust) on project success (see Table 4) indicate that both trust and distrust have a positive influence on project success on the whole. From this point of view, the influence of trust is far more important than that of distrust. Thus, trust and distrust are independent and have different functions. Generally, the function of distrust is to prevent risk [87].

Table 3. All the standardized path values of the structure equation model.

\begin{tabular}{cccc}
\hline & Relation of Variables & Path Value & Hypotheses \\
\hline \multirow{3}{*}{ Intermediate impact } & Outcome control $\rightarrow$ project success & $0.614^{*}$ & H4d: supported \\
& Behavior control $\rightarrow$ project success & $0.584^{*}$ & H4e: supported \\
& Social control $\rightarrow$ proejct success & $0.737^{*}$ & H4f: supported \\
\hline Influence between & Outcome control $\rightarrow$ social control & $-0.310^{*}$ & H1a: supported \\
intermediate variables & Behavior control $\rightarrow$ social control & $-0.256^{*}$ & H1b: supported \\
\hline & Calculative trust $\rightarrow$ outcome control & $0.276^{*}$ & H2a: supported \\
& Calculative trust $\rightarrow$ Behavior control & $0.294^{*}$ & H2b: supported \\
Influence from & Calculative trust $\rightarrow$ social control & $0.174^{*}$ & H2c: supported \\
independent variables on & Relational trust $\rightarrow$ outcome control & $-0.290^{*}$ & H2d: supported \\
intermediate variables & Relational trust $\rightarrow$ Behavior control & $-0.350^{*}$ & H2e: supported \\
& Relational trust $\rightarrow$ social control & $0.395^{*}$ & H2f: not supported \\
& distrust $\rightarrow$ outcomecontrol & $0.509^{*}$ & H3a: supported \\
& distrust $\rightarrow$ Behavior control & $0.612^{*}$ & H3b: supported \\
Influence from & distrust $\rightarrow$ social control & $0.334^{*}$ & H3c: supported \\
\hline independent variables & Calculative trust $\rightarrow$ project success & $0.220^{*}$ & H4a: supported \\
on dependent variable & Relationaltrust $\rightarrow$ project success & $0.313^{*}$ & H4b: supported \\
\hline & distrust $\rightarrow$ project success & $-0.636^{*}$ & H4c: supported \\
\hline
\end{tabular}

* Significance level is less than 0.05 .

Table 4. Impacts of independent variables on project success.

\begin{tabular}{cccc}
\hline \multirow{2}{*}{ Independent Variable } & \multicolumn{3}{c}{ Project Success } \\
\cline { 2 - 4 } & Direct Effect & Indirect Effect & Total Effect \\
\hline Calculative trust & 0.220 & 0.351 & 0.571 \\
Relational trust & 0.313 & 0.041 & 0.354 \\
distrust & -0.636 & 0.684 & 0.048 \\
\hline
\end{tabular}

\section{Discussion}

\subsection{The Effect of Distrust on Project Success}

Distrust has a directly negative influence on project success in accordance with the hypothesis. In contrast, greater attention should be paid to the positive and indirect influence of distrust. Outcome control, behavior control, and social control mediate this kind of positive and indirect influence. The internal logic is that the increase of distrust may contribute to more strength of control, and control is the measure to realize project targets. Therefore, distrust has an indirect and positive influence on project success by mediating the three control measures.

The positive influence of distrust should also be seen in project interorganizational relationship management. This kind of positive influence is weak compared with the effect of trust. However, this outcome conflicts with common understandings that distrust is harmful and has a negative influence on the project success $[88,89]$. Both trust and distrust provide healthy and positive mechanism for project cooperation. However, "over trust" and "distrust with bias" are detrimental to project success. Excessive trust may lead to opportunistic behavior, which is harmful to the success of cooperation. 
Similarly, distrust with biases can lead to irrational control, which is not beneficial to smooth progress of cooperation.

\subsection{The Relationship Between Trust and Control}

All hypotheses about the relationship between trust and control were supported, except the relationship between relational trust and social control. It was hypothesized that calculative trust has a positive influence on the three kinds of control, and relational trust has a negative influence on control. Das and Teng [24] pointed out that "the implementation of control in business organizations requires a certain level of trust." Similarly, in construction projects, it is necessary to sustain a certain level of trust to effectively control a partner.

However, the relationship between relational trust and social control is an exception. The empirical data from this study demonstrated that relational trust could increase social control. Relational trust contains affect-based and cognition-based trust, which are foundations for interpersonal and interorganizational cooperation [34]. Trust is cognition based in that "we choose whom we will trust in which respects and under what circumstances, and we base the choice on what we take to be 'good reasons,' constituting evidence of trust-worthiness" [34]. This kind of trust is cognition-based trust.

Social control relies on organizational norms, values, and the internalization of goals to encourage desirable outcomes and behaviors [90]. As a result, relational trust and social control have a natural intrinsic connection. Relational trust means the two partners have mutual recognition and the same value orientation. Two partners with same value orientation would communicate through norms and organizational culture, leading to greater strength of social control. Therefore, in construction projects, the owner and the contractor with high identification of value and culture would naturally interact with each other with a high level of spirit.

This result aligns with some studies concerning the relationship between relational trust and social control. The Aulakh et al. [91] study revealed social control positively correlates with goodwill trust in alliances. In fact, goodwill trust relates to relational trust. Saparito et al. [92] suggested relational trust is goodwill oriented.

\subsection{The Effect of Trust and Control}

\subsubsection{The Influence of Trust and Control on Project Success}

Calculative trust and relational trust have positive influence on project success. Previous studies showed that the direct influence of calculative trust on project success is less than that of relational trust, similar to this study [52]. However, this study also revealed that the indirect influence of calculative trust is far greater than that of relational trust. For calculative trust, indirect influence is also greater than direct influence.

Calculative trust and relational trust are supplementary in influencing the three kinds of control. The direct influence of relational trust on project success is high whereas the indirect influence of calculative trust on project success is high. In conclusion, calculative trust and relational trust play a joint critical role in achieving the project success.

Study results showed that all three kinds of control have a significant and positive influence on project success because the aim of control measures is to realize the targets set at the beginning of the project $[20,93]$. However, the influence of social control is the most important, followed by outcome control and behavior control. Previous studies have paid more attention to formal control (i.e., outcome control and behavior control [94]). Therefore, owners' project managers should be aware of the critical role of social control.

The impact of the three kinds of control can be understood from the outlook of philosophy. Social control is the highest level of management control because the controller exerts culture, value, and norm influence, influencing the controller to execute project tasks automatically. Outcome control is similar to management by objectives. The controller pays most attention to the result, and exerts pressure on 
the controller if the result does not meet the requirements. Behavior control attends to the process or procedure of projects wherein the controller may lose original project targets. This philosophy is in accord with Confucius: You will get secondary outcomes when setting goals high and low results when goals are set secondarily [95].

In summary, the effect of control on spiritual level (social control) is higher than that of control on objective management (outcome control). The effect of control in objective management is greater than that of control in process or procedure (behavior control).

\subsubsection{Mixed Impacts on Project Success (Most Influencing Factors/Paths)}

The SEM showed that all independent variables have a positive influence on project success. All three kinds of control have strong effects on project success. Calculative trust, relational trust, and distrust direct and indirect influence on project success. Calculative trust and relational trust have complementary effects on the three kinds of control. In addition, the overall effect (containing direct and indirect) of calculative trust is stronger than that of relational trust. Distrust has strong direct and indirect effects on project success. However, the whole effect of distrust on project success is relatively low.

\section{Conclusions}

This research made a theoretical contribution to trust in construction projects. A theoretical model containing trust (calculative trust and relational trust), distrust, control, and project success was proposed in this study. This model was tested by empirical data through SEM. The main contribution of this research was to develop a framework combining trust, distrust, and control and exploring relationships among them. In contrast, the majority of extant studies examined the relationship between trust and distrust or between trust and control separately [17,18].

Results revealed a complex relationship between trust and control. Calculative trust has a positive influence on the three kinds of control. Relational trust has a negative impact on outcome control and behavior control, and a positive impact on social control. Relational trust and social control have a natural connection. Relational trust means a high level of recognition and identification, which is beneficial when exerting social control. Results also showed that all independent variables (trust, distrust, and control) have a positive influence on project success. Calculative trust and relational trust influence project success with direct and indirect effects. Among the three kinds of control, social control is of greatest importance in achieving project success, though outcome control and behavior control have influence on project success by partly mediating social control. Distrust has strong direct and indirect effects on achieving project success. However, the overall effect of distrust on project success is relatively low.

This study has practical implications:

First, project managers should be aware that trust and distrust provide mechanisms to promote cooperation among stakeholders. Although distrust has a direct and negative effect on project success, it can play a positive role in mediating control. In construction projects, distrust is a normal and prevalent state for owners. Project managers should acknowledge the existence of distrust and use control measures to ensure project success. Indeed, trust and distrust relate positively and jointly have a significant impact on project success. However, "over trust" and "distrust with bias" are detrimental to project management. Therefore, project managers should assess the relationships with owners and provide suitable trust and distrust for the other partner. Appropriate control measures, based on the assessment of trust and distrust, would increase the likelihood of project success.

Second, it is valuable for project managers and owners to evaluate the trust on contractors and take proper control strategies, because the main function of distrust is to avoid risks but not on project success. If there is a high level of trust, it would be wise for project owners to exploit control measures for contractors at a low level, which is necessary for avoiding betrayal risks of contractors. If there 
is a low level of trust, it would be wise for project owners to exploit control measures at a high level, which mainly aims at achieving project success.

Third, of the three kinds of control measures, social control has the strongest impact on project success, with outcome control second and behavior control last. Project managers should pay attention to social control, taking full advantage of organizational culture and values to influence contractors to complete project tasks. Moreover, project managers should ensure all project objectives are realistic.

Finally, trust and control both affect project success. This should draw the attention of project managers. As shown in Table 3, project success will be in doubt without either of these two factors in place. In particular, among the three kinds of control, social control has the most significant impact on project success. Relational trust is the most important factor to influence social control. Therefore, special attention should be paid to nurturing relational trust of the owners toward the contractors. All the findings and suggestions are concluded in Table 5.

Table 5. Findings and suggestions.

\begin{tabular}{cll}
\hline & \multicolumn{1}{c}{ Findings } & \multicolumn{1}{c}{ Suggestions } \\
\hline 1 & $\begin{array}{l}\text { Distrust has an indirect and positive influence } \\
\text { on project success }\end{array}$ & $\begin{array}{l}\text { Project managers and owners should } \\
\text { acknowledge the existence of distrust and use } \\
\text { control measures to ensure project success }\end{array}$ \\
\hline 2 & Trust has certain effect on control & $\begin{array}{l}\text { Project managers and owners should evaluate } \\
\text { trust and take proper control strategy }\end{array}$ \\
\hline 3 & $\begin{array}{l}\text { Of all the three kinds of control, social control } \\
\text { has the strongest effect on project success }\end{array}$ & $\begin{array}{l}\text { Project managers and owners should pay } \\
\text { attentions to social control }\end{array}$ \\
\hline 4 & Trust and control both affect project success & Both trust and control should be paid attention \\
\hline
\end{tabular}

This research had some limitations. This research examined the effect of trust on control, yielding a complex relationship. Control influences trust [24]. Therefore, future research opportunities exist to examine the dynamic relationship between trust and control. For example, longitude data could be used to explore the relationship between trust and control. Also, the single source data tend to bring about common method biases [96,97]. Moreover, some control variables were not considered in this research, such as the competence of the contractor and the attitude or propensity of the owner. Similarly, other stakeholders of construction projects could be considered in future research.

Acknowledgments: This project was sponsored by the National Natural Science Foundation of China (Grant No. 71503171) and the Natural Science Foundation of Guangdong Province, China (Grant No. 2017A030310355).

Author Contributions: Weiping Jiang designed the study and completed the paper in English. Xianbo Zhao and Jian Zuo gave research advice.

Conflicts of Interest: The authors declare no conflicts of interest.

\section{References}

1. Bygballe, L.E.; Jahre, M.; Swärd, A. Partnering relationships in construction: A literature review. J. Purchas. Suppl. Manag. 2010, 16, 239-253. [CrossRef]

2. Chow, P.T.; Cheung, S.O.; Chan, K.Y. Trust-building in construction contracting: Mechanism and expectation. Int. J. Proj. Manag. 2012, 30, 927-937. [CrossRef]

3. Wu, G.; Zhao, X.; Zuo, J. Relationship between project's added value and the trust-conflict interaction among project teams. J. Manag. Eng. 2017, 33, 04017011. [CrossRef]

4. Rousseau, D.M.; Sitkin, S.B.; Burt, R.S.; Camerer, C. Not so different after all: A cross-discipline view of trust. Acad. Manag. Rev. 1998, 23, 393-404. [CrossRef]

5. Wong, W.K.; Cheung, S.O.; Yiu, T.W.; Pang, H.Y. A framework for trust in construction contracting. Int. J. Proj. Manag. 2008, 26, 821-829. [CrossRef] 
6. Black, C.; Akintoye, A.; Fitzgerald, E. An analysis of success factors and benefits of partnering in construction. Int. J. Proj. Manag. 2000, 18, 423-434. [CrossRef]

7. Bohnet, I.; Zeckhauser, R. Trust, risk and betrayal. J. Econ. Behav. Organ. 2004, 55, 467-484. [CrossRef]

8. Kalkman, J.P.; de Waard, E.J. Inter-organizational disaster management projects: Finding the middle way between trust and control. Int. J. Proj. Manag. 2016, 35, 889-899. [CrossRef]

9. Leifer, R.; Mills, P.K. An information processing approach for deciding upon control strategies and reducing control loss in emerging organizations. J. Manag. 1996, 22, 113-137. [CrossRef]

10. Lewicki, R.J.; McAllister, D.J.; Bies, R.J. Trust and distrust: New relationships and realities. Acad. Manag. Rev. 1998, 23, 438-458.

11. Seckler, M.; Heinz, S.; Forde, S.; Tuch, A.N.; Opwis, K. Trust and distrust on the web: User experiences and website characteristics. Comput. Hum. Behav. 2015, 45, 39-50. [CrossRef]

12. Kramer, R.M. Trust and distrust in organizations: emerging perspectives, enduring questions. Ann. Rev. Psychol. 1999, 50, 569-598. [CrossRef] [PubMed]

13. Bigley, G.A.; Pearce, J.L. Straining for shared meaning in organization science: Problems of trust and distrust. Acad. Manag. Rev. 1998, 23, 405-421.

14. Luhmann, N. Trust and Power; John Wiley and Sons: Manchester, UK, 1979.

15. Sitkin, S.B.; Roth, N.L. Explaining the limited effectiveness of legalistic "remedies" for trust/distrust. Organ. Sci. 1993, 4, 367-392. [CrossRef]

16. Mcknight, D.H.; Chervany, N.L. Trust and Distrust Definitions: One Bite at a Time. In Trust in Cyber-Societies; Springer: Berlin, Germany, 2001; pp. 27-54.

17. Vlaar, P.W.; Van den Bosch, F.A.; Volberda, H.W. On the evolution of trust, distrust, and formal coordination and control in interorganizational relationships toward an integrative framework. Group Organ. Manag. 2007, 32, 407-428. [CrossRef]

18. Agndal, H.; Nilsson, U. Interorganizational cost management in the exchange process. Manag. Account. Res. 2009, 20, 85-101. [CrossRef]

19. Chinowsky, P.S.; Diekmann, J.; O’Brien, J. Project organizations as social networks. J. Constr. Eng. Manag. 2009, 136, 452-458. [CrossRef]

20. Acebes, F.; Pajares, J.; Galán, J.M.; López-Paredes, A. A new approach for project control under uncertainty. Going back to the basics. Int. J. Proj. Manag. 2014, 32, 423-434. [CrossRef]

21. Vanhoucke, M. Integrated Project Management and Control; Springer: Berlin, Germany, 2014.

22. Colin, J.; Vanhoucke, M. Developing a framework for statistical process control approaches in project management. Int. J. Proj. Manag. 2015, 33, 1289-1300. [CrossRef]

23. Eisenhardt, K.M. Control: Organizational and economic approaches. Manag. Sci. 1985, 31, $134-149$. [CrossRef]

24. Das, T.K.; Teng, B.S. Trust, control, and risk in strategic alliances: An integrated framework. Organ. Stud. 2001, 22, 251-283. [CrossRef]

25. Dekker, H.C. Control of inter-organizational relationships: Evidence on appropriation concerns and coordination requirements. Account. Organ. Soc. 2004, 29, 27-49. [CrossRef]

26. Pfeffer, J.; Salancik, G.R. The External Control of Organizations: A Resource Dependence Perspective; Stanford University Press: Stanford, CA, USA, 2003.

27. Cravens, D.W.; Lassk, F.G.; Low, G.S.; Marshall, G.W.; Moncrief, W.C. Formal and informal management control combinations in sales organizations: The impact on salesperson consequences. J. Bus. Res. 2004, 57, 241-248. [CrossRef]

28. Kirsch, L.J.; Ko, D.G.; Haney, M.H. Investigating the antecedents of team-based clan control: Adding social capital as a predictor. Organ. Sci. 2010, 21, 469-489. [CrossRef]

29. Turner, J.R.; Simister, S.J. Project contract management and a theory of organization. Int. J. Proj. Manag. 2001, 19, 457-464. [CrossRef]

30. Müller, R.; Turner, J.R. The impact of principal-agent relationship and contract type on communication between project owner and manager. Int. J. Proj. Manag. 2005, 23, 398-403. [CrossRef]

31. Dey, P.K. Process re-engineering for effective implementation of projects. Int. J. Proj. Manag. 1999, 17, 147-159. [CrossRef]

32. Doney, P.M.; Cannon, J.P. An examination of the nature of trust in buyer-seller relationships. J. Market. 1997, 61, 35-51. [CrossRef] 
33. Schoder, D.; Haenlein, M. The relative importance of different trust constructs for sellers in the online world. Electr. Mark. 2004, 14, 48-57. [CrossRef]

34. McAllister, D.J. Affect-and cognition-based trust as foundations for interpersonal cooperation in organizations. Acad. Manag. J. 1995, 38, 24-59. [CrossRef]

35. Lewicki, R.J.; Bunker, B.B. Developing and maintaining trust in work relationships. In Trust in Organizations: Frontiers of Theory and Research; Sage Publications: Thousand Oaks, CA, USA, 1996; pp. 114-139.

36. Williamson, O.E. Calculated trust, a reply to craswell's comment on williamson. J. Law Econ. 1993, 36, 501-502. [CrossRef]

37. Poppo, L.; Zenger, T. Do formal contracts and relational governance function as substitutes or complements. Strateg. Manag. J. 2002, 23, 707-725. [CrossRef]

38. Das, T.K.; Teng, B.S. Between trust and control: Developing confidence in partner cooperation in alliances. Acad. Manag. Rev. 1998, 23, 491-512.

39. Govier, T. Is it a jungle out there? Trust, distrust and the construction of social reality. Dialogue 1994, 33, 237-252. [CrossRef]

40. Sundaramurthy, C.; Lewis, M. Control and collaboration: Paradoxes of governance. Acad. Manag. Rev. 2003, 28, 397-415.

41. Cho, J. The mechanism of trust and distrust formation and their relational outcomes. J. Retail. 2006, 82, 25-35. [CrossRef]

42. Aghion, P.; Dewatripont, M.; Hoxby, C.; Mas-Colell, A.; Sapir, A. The governance and performance of universities: evidence from Europe and the US. Econ. Policy 2010, 25, 7-59. [CrossRef]

43. Zaghloul, R.; Hartman, F. Construction contracts: the cost of mistrust. Int. J. Proj. Manag. 2003, 21, 419-424. [CrossRef]

44. Liu, G.; Shen, Q.; Li, H.; Shen, L. Factors constraining the development of professional project management in China's construction industry. Int. J. Proj. Manag. 2004, 22, 203-211. [CrossRef]

45. Alzahrani, J.I.; Emsley, M.W. The impact of contractors' attributes on construction project success: A post construction evaluation. Int. J. Proj. Manag. 2013, 31, 313-322. [CrossRef]

46. Serra, C.E.M.; Kunc, M. Benefits Realisation Management and its influence on project success and on the execution of business strategies. Int. J. Proj. Manag. 2015, 33, 53-66. [CrossRef]

47. Lim, C.S.; Mohamed, M.Z. Criteria of project success: An exploratory re-examination. Int. J. Proj. Manag. 1999, 17, 243-248. [CrossRef]

48. Wang, X.; Huang, J. The relationships between key stakeholders' project performance and project success: Perceptions of Chinese construction supervising engineers. Int. J. Proj. Manag. 2006, 24, 253-260. [CrossRef]

49. De Wit, A. Measurement of project success. Int. J. Proj. Manag. 1988, 6, 164-170. [CrossRef]

50. Cheung, E.; Chan, A.P.; Kajewski, S. Factors contributing to successful public private partnership projects: Comparing Hong Kong with Australia and the United Kingdom. J. Facilit. Manag. 2012, 10, 45-58. [CrossRef]

51. Dvir, D.; Raz, T.; Shenhar, A.J. An empirical analysis of the relationship between project planning and project success. Int. J. Proj. Manag. 2003, 21, 89-95. [CrossRef]

52. Jiang, W.; Lu, Y.; Le, Y. Trust and Project Success: A Twofold Perspective between Owners and Contractors. J. Manag. Eng. 2016, 32, 04016022. [CrossRef]

53. Diallo, A.; Thuillier, D. The success of international development projects, trust and communication: an African perspective. Int. J. Proj. Manag. 2005, 23, 237-252. [CrossRef]

54. Maurer, I. How to build trust in inter-organizational projects: The impact of project staffing and project rewards on the formation of trust, knowledge acquisition and product innovation. Int. J. Proj. Manag. 2010, 28, 629-637. [CrossRef]

55. Wu, G.; Zhao, X.; Zuo, J. Effects of inter-organizational conflicts on construction project added value in China. Int. J. Conf. Manag. 2017, 28, 695-723. [CrossRef]

56. Kadefors, A. Trust in project relationships-Inside the black box. Int. J. Proj. Manag. 2004, 22, 175-182. [CrossRef]

57. Ou, C.X.; Sia, C.L. To trust or to distrust, that is the question: investigating the trust-distrust paradox. Communic. ACM 2009, 52, 135-139. [CrossRef]

58. Benamati, J.; Serva, M.A. Trust and distrust in online banking: Their role in developing countries. Inform. Technol. Dev. 2007, 13, 161-175. [CrossRef] 
59. McKnight, D.H.; Choudhury, V. Distrust and trust in B2C e-commerce: Do they differ? In Proceedings of the 8th International Conference on Electronic Commerce: The New E-commerce: Innovations for Conquering Current Barriers, Obstacles and Limitations to Conducting Successful Business on the Internet, Fredericton, NB, Canada, 13-16 August 2006; pp. 482-491.

60. Malmi, T.; Brown, D.A. Management control systems as a package-Opportunities, challenges and research directions. Manag. Account. Res. 2008, 19, 287-300. [CrossRef]

61. Burke, R. Project Management: Planning and Control Techniques; Wiley: Hoboken, NJ, USA, 2013.

62. Kirsch, L.J. The management of complex tasks in organizations: Controlling the systems development process. Organ. Sci. 1996, 7, 1-21. [CrossRef]

63. Hair, J.F.; Black, W.C.; Babin, B.J.; Anderson, R.E.; Tatham, R.L. Multivariate Data Analysis; Pearson Prentice Hall: Upper Saddle River, NJ, USA, 2006.

64. Le, Y.; Shan, M.; Chan, A.P.C.; Hu, Y. Investigating the causal relationships between causes of and vulnerabilities to corruption in the Chinese public construction sector. J. Constr. Eng. Manag. 2014, 140, 05014007. [CrossRef]

65. Zhao, X.; Singhaputtangkul, N. Effects of firm characteristics on enterprise risk management: Case study of Chinese construction firms operating in Singapore. J. Manag. Eng. 2016, 32, 05016008.

66. Handfield, R.B.; Bechtel, C. The role of trust and relationship structure in improving supply chain responsiveness. Industr. Market. Manag. 2002, 31,367-382. [CrossRef]

67. Zaheer, A.; Mcevily, B.; Perrone, V. Does trust matter? Exploring the effects of interorganizational and interpersonal trust on performance. Organ. Sci. 1998, 9, 141-159. [CrossRef]

68. Yang, J. The Occurrence Mechanism of Trust between Enterprises in Supply Chain and its Effect on Cooperation. Ph.D. Thesis, Zhejiang University, Hangzhou, China, 2006.

69. Chen, Y. The Occurrence Mechanisms of Trust and Distrust in Online Shopping of Chinese Consumers. Ph.D. Thesis, Jilin University, Changchun, China, 2010.

70. Jap, S.D.; Ganesan, S. Control mechanisms and the relationship life cycle: Implications for safeguarding specific investments and developing commitment. J. Market. Res. 2000, 37, 227-245. [CrossRef]

71. Zhang, Y. The Effects of Trust and Control on Cooperation Risk and Performance; Shanghai University of Finance and Economics Press: Shanghai, China, 2007.

72. Cheung, S.O. Trust in Co-operative Contracting in Construction; City University of HK Press: Hong Kong, China, 2007.

73. Cheung, S.O.; Ng, T.S.; Wong, S.P.; Suen, H.C. Behavioral aspects in construction partnering. Int. J. Proj. Manag. 2003, 21, 333-343. [CrossRef]

74. Jeffrey, S.; Richards, J.; Ciravegna, F.; Waller, S.; Chapman, S.; Zhang, Z. The archaeotools project: faceted classification and natural language processing in an archaeological context. Philosoph. Transact. Mathematic. Phys. Eng. Sci. 2009, 367, 2507-2519. [CrossRef] [PubMed]

75. Jugdev, K.; Muller, R. A retrospective look at our evolving understanding of project success. Proj. Manag. J. 2005, 36, 19-31. [CrossRef]

76. Shan, M.; Chan, A.P.C.; Le, Y.; Hu, Y. Investigating the effectiveness of response strategies for vulnerabilities to corruption in the Chinese public construction sector. Sci. Eng. Ethics 2015, 21, 683-705. [CrossRef] [PubMed]

77. Anvuur, A.M.; Kumaraswamy, M.; Fellows, R. Perceptions of status and TMO workgroup cooperation: implications for project governance. Constr. Manag. Econ. 2012, 30, 719-737. [CrossRef]

78. Gorsuch, R.L.; Ortberg, J. Moral obligation and attitudes: Their relation to behavioral intentions. J. Personal. Soc. Psychol. 1983, 44, 1025. [CrossRef]

79. Bagozzi, R.P.; Yi, Y. Specification, evaluation, and interpretation of structural equation models. J. Acad. Market. Sci. 2012, 40, 8-34. [CrossRef]

80. Chen, Y.S.; Chang, C.H. Greenwash and green trust: The mediation effects of green consumer confusion and green perceived risk. J. Bus. Ethics 2013, 114, 489-500. [CrossRef]

81. Nunnally, J. Psychometric Theory; McGraw-Hill: New York, NY, USA, 1978.

82. Wong, P.S.P.; Cheung, S.O. Structural equation model of trust and partnering success. J. Manag. Eng. 2005, 21, 70-80. [CrossRef]

83. Hair, J.F.; Anderson, R.E.; Tatham, R.L.; Black, W.C. Multivariate Data Analysis, 5th ed.; Pearson Education Limited: Harlow, UK, 1998. 
84. Medsker, G.J.; Williams, L.J.; Holahan, P.J. A review of current practices for evaluating causal models in organizational behavior and human resources management research. J. Manag. 1994, 20, 439-464. [CrossRef]

85. Chen, F.; Curran, P.J.; Bollen, K.A.; Kirby, J.; Paxton, P. An empirical evaluation of the use of fixed cutoff points in RMSEA test statistic in structural equation models. Sociol. Methods Res. 2008, 36, 462-494. [CrossRef] [PubMed]

86. Bollen, K.A. A new incremental fit index for general structural equation models. Sociol. Methods Res. 1989, 17, 303-316. [CrossRef]

87. McKnight, D.H.; Kacmar, C.J.; Choudhury, V. Dispositional trust and distrust distinctions in predicting high-and low-risk internet expert advice site perceptions. E-Serv. J. 2004, 3, 35-55. [CrossRef]

88. Sabherwal, R. The role of trust in outsourced IS development projects. Communic. ACM 1999, 42, 80-86. [CrossRef]

89. Cheung, S.O.; Yiu, T.W.; Man, C.L. Interweaving trust and communication with project performance. J. Constr. Eng. Manag. 2013, 139, 941-950. [CrossRef]

90. Ingram, T.N.; LaForge, R.W.; Schwepker Jr, C.H. Sales person ethical decision making: The impact of sales leadership and sales management control strategy. J. Person. Sell. Sales Manag. 2007, 27, 301-315. [CrossRef]

91. Aulakh, P.S.; Kotabe, M.; Sahay, A. Trust and performance in cross-border marketing partnerships: A behavioral approach. J. Int. Bus. Stud. 1996, 27, 1005-1032. [CrossRef]

92. Saparito, P.A.; Chen, C.C.; Sapienza, H.J. The role of relational trust in bank-small firm relationships. Acad. Manag. J. 2004, 47, 400-410. [CrossRef]

93. Vanhoucke, M. Measuring the efficiency of project control using fictitious and empirical project data. Int. J. Proj. Manag. 2012, 30, 252-263. [CrossRef]

94. Lee, G.; Shin, G.C.; Haney, M.H.; Kang, M.; Li, S.; Ko, C. The impact of formal control and guanxi on task conflict in outsourcing relationships in China. Industr. Market. Manag. 2017, 62, 128-136. [CrossRef]

95. Reid, T.R. Confucius Lives Next Door: What Living in the East Teaches Us about Living in the West; Vintage: New York, NY, USA, 2013.

96. Jiang, Z. Core self-evaluation and career decision self-efficacy: A mediation model of value orientations. Pers. Individ. Dif. 2015, 86, 450-454. [CrossRef]

97. Jiang, Z. The relationship between career adaptability and job content plateau: The mediating roles of fit perceptions. J. Vocat. Behav. 2016, 95-96, 1-10. [CrossRef] 